\title{
All is well
}

Citation for published version (APA):

Haak, H. R. (2014). All is well. Maastricht University. https://doi.org/10.26481/spe.20140704hh

Document status and date:

Published: 04/07/2014

DOI:

10.26481/spe.20140704hh

Document Version:

Publisher's PDF, also known as Version of record

\section{Please check the document version of this publication:}

- A submitted manuscript is the version of the article upon submission and before peer-review. There can be important differences between the submitted version and the official published version of record.

People interested in the research are advised to contact the author for the final version of the publication, or visit the DOI to the publisher's website.

- The final author version and the galley proof are versions of the publication after peer review.

- The final published version features the final layout of the paper including the volume, issue and page numbers.

Link to publication

\footnotetext{
General rights rights.

- You may freely distribute the URL identifying the publication in the public portal. please follow below link for the End User Agreement:

www.umlib.nl/taverne-license

Take down policy

If you believe that this document breaches copyright please contact us at:

repository@maastrichtuniversity.nl

providing details and we will investigate your claim.
}

Copyright and moral rights for the publications made accessible in the public portal are retained by the authors and/or other copyright owners and it is a condition of accessing publications that users recognise and abide by the legal requirements associated with these

- Users may download and print one copy of any publication from the public portal for the purpose of private study or research.

- You may not further distribute the material or use it for any profit-making activity or commercial gain

If the publication is distributed under the terms of Article $25 \mathrm{fa}$ of the Dutch Copyright Act, indicated by the "Taverne" license above, 
Maastricht University Lending in Lamm!

Prof. dr. Harm R. Haak

Faculty of Health, Medicine and Life Sciences

\section{"All is well"}


"All is Well" 


\section{Colofon}

Ontwerp \& print: Canon Business Services, Maastricht

Omslag: Anton Henning. Interieur \# 86. Olie op canvas, 2001, $193 \times 213 \mathrm{~cm}$.

ISBN: 978-90-5681-433-5

NUR: 878

Alle rechten voorbehouden. Niets uit deze uitgave mag worden verveelvoudigd, opgeslagen in een geautomatiseerd gegevensbestand of openbaar gemaakt worden, zonder voorafgaande schriftelijke toestemming van de auteur of uitgever. 


\section{"All is Well"}

Oratie Prof.dr. Harm R. Haak

Maastricht, 4 juli 2014

Prof.dr. Harm R. Haak 
"All is Well" 
Mijnheer de Rector Magnificus, zeer gewaardeerde toehoorders.

\section{All is Well.}

Ja, met mij is alles wel. Ik ben vereerd en blij met mijn benoeming en met de uitdagingen die dat met zich meebrengt.

Die uitdagingen zijn voor mij de thema's voor de toekomst van de acute geneeskunde:

1. het herkennen van kwetsbare patiënten,

2. het organiseren van het team voor de spoedeisende zorg, en

3. aandacht voor de logistiek. De doelstelling is daarbij een doelmatige en veilige zorgverlening.

Is die er dan nu niet hoor ik u denken? Nou: ja en nee.

All is Well; het is goed, houen zo, niets meer aan doen.

Dit is een standaardhouding van veel mensen. Is dat terecht?

Het klopt dat veel voorgestelde veranderingen geen verbeteringen zijn. Maar als we terugkijken naar het verleden zien we toch dat er veel veranderd en veel verbeterd is. Dan verbazen we ons erover dat we het vroeger zo moesten doen en dat we toen tevreden waren.

Die houding van tevreden zijn met wat we hebben en van liever niets willen veranderen a.u.b., zie ik ook op het terrein van de acute geneeskunde.

Mijn verhaal gaat over toen, over nu en over straks.

Over acute interne geneeskunde in het ziekenhuis.

Over dokters en andere werkers in de zorg in ziekenhuizen.

Ziekenhuis, wat is een ziekenhuis? Wat is een ziekenhuis, gezien vanuit het perspectief van de patiënt, de consument?

Een ziekenhuis is een plek waar gewacht wordt. Mensen wachten er op uitleg, op een behandeling of een medische oplossing. Ongerust en vol onzekerheid komen ze er binnen, bang om de touwtjes uit handen te moeten geven. Toch moeten ze geduld hebben en op hun beurt wachten. Terwijl zij dat doen kunnen ze afleiding zoeken door in wachtruimtes een tijdschrift door te bladeren of naar andere patiënten te kijken en proberen het doel van hun bezoek te raden. Zo hoeven ze even niet aan de reden van hun eigen bezoek te denken. ${ }^{1}$ Gedachten dwalen af. Denken over andere zaken. De geest als teken van bestaan. 
We kunnen het ziekenhuis zien als een werkplaats waar menselijke lichamen worden gerepareerd, waar onderdelen (heupen, knieën etc.) vervangen worden. ${ }^{1}$ Wanneer de nadruk ligt op het herstellen van wat kapot is bestaat het gevaar dat er een scheiding optreedt tussen lichaam en ziel - en dat is een verontrustende gedachte. Scheiding van lichaam en geest. Ik herinner u aan Rene Descartes "ik denk dus ik ben".
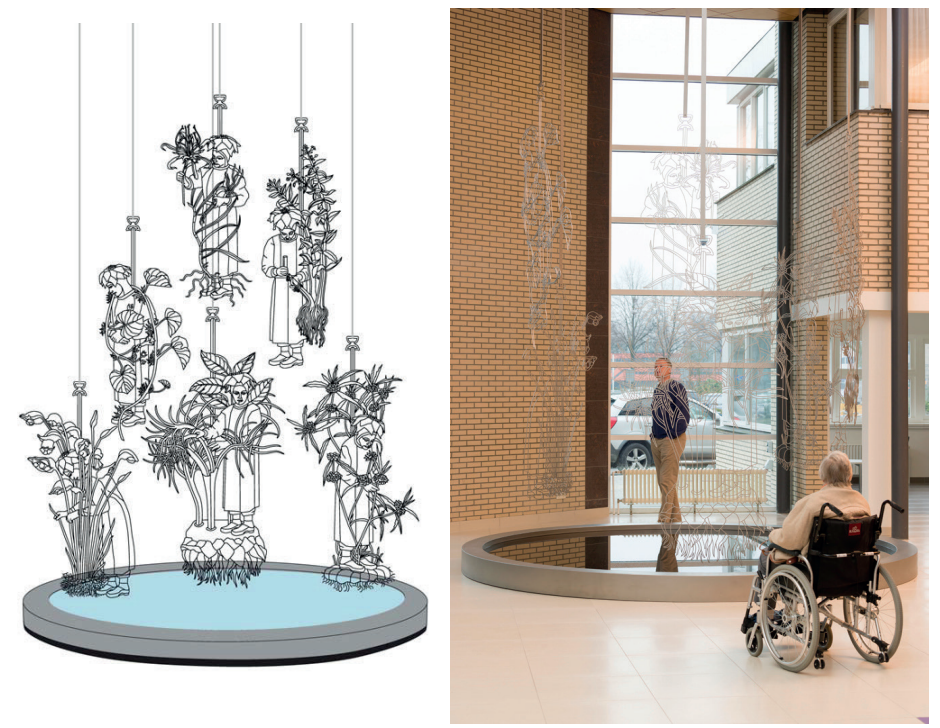

U ziet het kunstwerk van Aya Ben Ron, getiteld "All is Well". Het werk bevindt zich in de hal van het Máxima Medisch Centrum, locatie Eindhoven, met als doel daar een bijzondere plek voor bespiegeling en bezinning te creëren. Het kunstwerk confronteert ons met onze neiging om de realiteit te ontvluchten, en wil daarmee afrekenen.

Het werk bestaat uit een spiegelende vijver (met een diameter van 4 meter) met zwevend daarboven zes roestvrijstalen figuren (elk ongeveer $2,5 \times 1$ meter). De figuren met botanische elementen verwijzen naar de geschiedenis van de geneeskunde. Alle figuren hangen boven de vijver zonder het water te raken. Spiegelingen van het verleden in het heden. Oneindige diepte om terug te keren tot jezelf.

Een vijver, een well. Een bron van hoop, troost, reflectie. Een ziekenhuis als bron voor genezing.

"All is Well". 


\section{Toen}

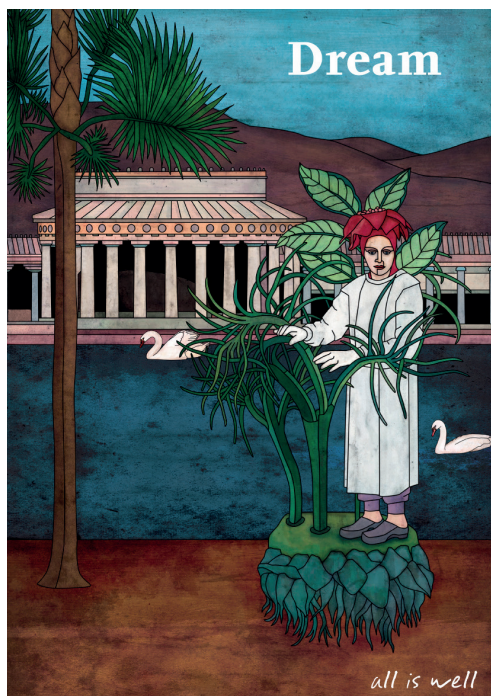

3

$U$ ziet een van de figuren van het kunstwerk van Aya Ben Ron. De figuur heet 'Dream' en is afgebeeld staande voor de tempel van Aesculapius.

De tempels van Aesculapius, we spreken over de $4^{\text {e }}$ eeuw voor Christus, werden bezocht door zieke mannen en vrouwen. Die tempels waren meestal bij een bron te vinden om daar de rite van de incubatie uit te voeren. De zieke mensen sliepen in de tempel en wachtten tot Aesculapius hen in hun slaap genas, of hen in een droom instructies zou geven voor een passende geneeswijze.

De tempels van Aesculapius zijn te beschouwen als de eerste ziekenhuizen.

Spoedeisende zorgposten avant la lettre.

Ik sla de verdere geschiedenis even over om uit te komen halverwege de jaren tachtig. Mijn begin als dokter in het Diaconessenhuis Hilversum. Ziekenhuizen kenden nog geen Spoedeisende Hulp zoals we die nu kennen. Bouwkundig niet en organisatorisch niet. Er was wel vaak een unit waar patiënten opgevangen konden worden. De ruimte daarvoor was oorspronkelijk voor andere doeleinden bestemd. Je kon daar als dokter in de nacht samen met een opgetrommelde verpleegkundige (het nachthoofd) de patiënt bekijken, onderzoeken en behandelen. Naar huis als er een oplossing was, of naar de algemene afdeling als er een behandeling in het ziekenhuis nodig was.

Overdag gingen patiënten die spoedzorg nodig hadden naar de poli of direct voor opname naar de afdeling.

Als beginnende dokter mocht ik toen naast de zorg voor de in het ziekenhuis opgenomen patiënten in het weekend alle spoedeisende zorg op beschouwend terrein leveren. Voor uw informatie, die dienst begon op vrijdagochtend en eindigde maandagavond. Was All toen Well? 
Er waren in die tijd zeker ook ziekenhuizen met EHBO's. Eerste Hulp Bij Ongelukken. Deze afdelingen waren, zoals de naam al suggereert, vooral chirurgisch georiënteerd. Gebroken arm, val op hoofd, gevolgen van verkeersongelukken etc. De EHBO werd bevolkt door doeners, flinke mensen, chirurgen en in de chirurgie werkzamen.

Internisten werden beschouwd als denkers, geen doeners. Toch hebben internisten al decennia, voor mij sinds mensenheugenis, spoedeisende zorg gedaan. Volgens de systemen en met de hulpmiddelen van die tijd. Internisten denken graag goed na voor ze tot actie overgaan. Maar als daar geen tijd voor is, zoals op de spoedeisende hulp, zijn internisten ook getraind om daadkrachtig en snel de situatie te overzien en te stabiliseren.

De twee gezichten van de internist: bedachtzaam, kalm, weloverwogen en handelend waar nodig.

Medio jaren 80 waren er ook ziekenhuizen met een niet-chirurgische spoedafdeling, voor de beschouwers, de internisten. In het Academisch Ziekenhuis Leiden trof ik in het vervolg van mijn opleiding zo'n afdeling: Acute Opname heette die. Daar kwamen patiënten, verwezen door huisartsen of poliklinieken, en ook zelfverwijzers, die ieder op hun beurt gezien en behandeld werden.

De acute opname was in een ander gebouw dan de EHBO. De chirurgen en de internisten apart. Een wereld van verschil.

Het verpleegkundig personeel van deze afdelingen was toegewijd en bekwaam, herinner ik me. De dokters waren enthousiast.

All Well 


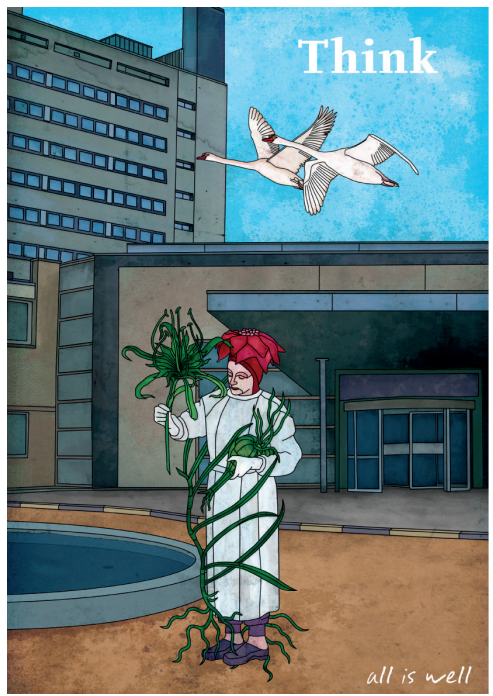

Deze figuur van Aya Ben Ron's kunstwerk is genaamd "Think", en hoort bij het Eindhovense Máxima Medisch Centrum in de 21ste eeuw. De tijd waarin laboratoriumonderzoeken en hightech machines het lichamelijk onderzoek verdringen. Dit beeld hoort bij het Nu.

\section{Nu 1, speelveld en spelers.}

Wat speelt er nu? Ik ga met u vier ontwikkelingen doornemen, achtereenvolgens:

1. het ontstaan van het subspecialisme acute interne geneeskunde

2. veranderingen in de organisatie van de chirurgie

3. het ontstaan van een nieuw specialisme, de SEH-geneeskunde

4. de veranderingen in de inrichting van de spoedzorg.

Ik begin bij de acute interne geneeskunde. Het is als subspecialisme in 2005 tijdens de ledenvergadering van de NIV officieel ingesteld. In 2009 is de sectie acute geneeskunde formeel van start gegaan. Die sectie onder leiding van Tom Geers en samen met alle andere strijders van het eerste uur, ik noem nu geen namen verder, heeft het subspecialisme en de opleiding verder ingericht.

Het curriculum van de acute interne geneeskunde is gericht op het kunnen leveren van prompte, hoogkwalitatieve zorg aan patiënten met een acute medische zorgvraag. Doelmatigheid als uitgangspunt. Samenwerking met andere zorgprofessionals als basisprincipe. Bijvoorbeeld met intensivisten in kritieke situaties. 
Er zijn inmiddels 95 internisten geregistreerd, waarvan 7 antegraad opgeleid. Er wordt in alle regio's opgeleid. Er is een uitstekende vereniging voor acute interne geneeskunde opgericht: "DAM". Er worden congressen en symposia gehouden, en er wordt scholing gegeven. Hoogtepunt tot nu was het congres samen met onze zustervereniging uit het Verenigd Koninkrijk, de "SAM", afgelopen mei in Amsterdam. Wetenschap wordt inmiddels lokaal en ook gezamenlijk uitgevoerd. Een consortium is geformeerd. De eerste trial, PHANTASi, is van start gegaan. Flash Mob onderzoek, ontwikkeld in Rotterdam Erasmus MC, volgt snel.

De ontwikkelingen brengen nu ook met zich mee het instellen van leerstoelen en bijhorende benoemingen. $U$ weet het wel, vandaag. All is Well.

Ik ga door naar de chirurgen.

Zij waren de specialisten van het eerste uur op de spoedzorg, de EHBO. In deze tijd hebben ze toenemend een capaciteitsprobleem voor de SEH. Het vak wordt steeds verder opgedeeld of uitgewerkt zo $u$ wilt in subspecialismen, waardoor niet iedereen alles kan en mag doen. De traumatologie op de SEH is voor de chirurgen van veel ziekenhuizen alleen niet meer volledig op te vangen. Door de modernisering van de opleiding mogen de aios' chirurgie niet meer zomaar alles op de SEH blijven doen. Immers er moet een volwaardig pakket aan ook andere vaardigheden en competenties verkregen worden. Opleiding voor productie. Zorg op SEH moet anders georganiseerd worden. Ik kom daarop terug.

Ik vervolg mijn betoog met de SEH-geneeskunde.

SEH-artsen zijn sinds enkele jaren op het toneel. Een nieuw specialisme. Zij worden in vele ziekenhuizen ingezet met een rol in de opvang van patiënten op de spoedeisende hulp. Hun opleiding is breed. Zij moeten de volle breedte van de specialistische zorg in acute setting kunnen leveren. De opleiding tot SEH-arts is echter nog in ontwikkeling. Ze beperkt zich helaas tot drie jaar waarin alle competenties moeten worden behaald. Die opleiding moet voor ten minste 50\% op de SEH worden gevolgd en omvat verder modules op de intensive care, anesthesiologie, cardiologie, kindergeneeskunde, huisartsgeneeskunde en regionale ambulance voorziening. Een module interne geneeskunde ontbreekt. Die module kan lokaal wel ingevuld worden. In MMC is dat een stage van 2 maanden.

De SEH-arts in Nederland wordt in vergelijking met de Emergency Physician in Engeland kort opgeleid. Die Emergency Physician heeft een weg van 10 jaar afgelegd tot aan de specialisatie en daarmee breder en dieper kennis gemaakt met specialistische spoedzorg. 
Inmiddels is het vak van SEH-arts officieel, door de Registratiecomissie Geneeskundig Specialisten, de RGS, erkend. Hun aantal is echter nog beperkt. De vraag naar hen is groter dan het aanbod. Zij zijn onderbemand voor de zorg die hen toebedeeld lijkt.

Dan naar de veranderende inrichting van de spoedzorg.

Er zijn nu zo'n 100 ziekenhuizen. En al die ziekenhuizen hebben een SEH. Bijna overal kan je 7×24 uur terecht. Op die spoedeisende hulpen werken getrainde en georganiseerde verpleegkundigen. Met een algemeen diploma, en soms een aantekening voor een specifieke zorgstroom. Opvang van kinderen bijvoorbeeld.

Diverse soorten van dokters werken er op deze SEH's. Chirurgen, orthopeden, internisten, longartsen etcetera. SEH-artsen inmiddels in veel, maar niet alle, ziekenhuizen ook. De SEH's van de ziekenhuizen hebben vaak de insteek: alles is welkom. Uitzonderingen zijn bijvoorbeeld grote trauma's met neurochirurgische problematiek.

Praktisch gesproken vindt de triage prehospitaal plaats via de verwijzers: huisartsen en ambulances. Zij weten uit ervaring waar je voor wat moet zijn. Afspraken.

Het grootste volume aan patiënten op de SEH bevindt zich op het terrein van de chirurgie. Traumatologie, gebroken botten en zo. Verder zijn er bijvoorbeeld acute buikbeelden en andere zaken. De SEH is, misschien was, een grote werkplek voor het vrije beroep van medisch specialist. De SEH als een belangrijke economische factor. Ook voor internisten was en is dat nog steeds het geval. Deze economische drijfveren stonden vooruitgang in de weg.

Het is goed, houen zo, niets meer aan doen. All is Well.

Om dat te doorbreken moet er bestuurlijk van hogerhand iets gebeuren. Organisatie, missie.

De overheid, en voor hen de zorgverzekeraars, heeft de belangrijke missie de kosten in de zorg te beheersen. Met behoud van kwaliteit natuurlijk. Wijzigingen in het systeem zijn jarenlang voorgesteld. Werkelijke veranderingen steeds tegengehouden of gefrustreerd. Tot het moment dat de regie vast in handen van de zorgverzekeraar kwam. Contracten kunnen nu afgesloten worden voor goede zorg, volumenormen inbegrepen. En dus kunnen instellingen ook géén contracten krijgen voor delen van de zorg. 
SEH's worden gelicenseerd voor allerlei type patiënten en zorgstromen: neurologische zorg (CVA), heelkundige zorg (acuut aneurysma), acute cardiologische zorg en multitraumazorg. Hieraan gekoppeld zijn de faciliteiten en capaciteit van de operatiecomplexen en intensive care afdelingen.

De spoedeisende hulpen worden gerelateerd aan huisartsenposten. Het doel is samen onder één dak te komen. Gereguleerde zorgstromen tussen eerste en tweede lijn. Een grote wijziging op de kaart van de spoedeisende hulpen en achterliggende ziekenhuizen is aanstaande.

De Gezondheidsraad heeft in 2012 de minister hieromtrent advies gegeven waarbij de bereikbaarheid, de juiste bezetting van de SEH en de afstemming van de spoedeisende zorg in de regio de thema's vormden.

De zorgverzekeraars gaan, indien hun plannen realiteit worden, ziekenhuizen contracteren op 3 types acute zorg aan de poort: "basis, profiel en compleet". De verschillende SEH's zullen als het ware in een keten moeten functioneren. Er blijven in deze constructie dan mogelijk slechts 50 volledige SEH's in het land die 7×24 uur open zijn. De andere SEH's zijn beperkt open, in principe tijdens kantoortijden, soms ook daarbuiten.

Ziekenhuizen moeten de organisatie van hun SEH inrichten met inachtneming van alle normen en verplichtingen die zorgverzekeraars en patiënten, tezamen de maatschappij vormend, van hen vragen.

Die organisatie moet dus van de koninkrijken chirurgie en interne een coöperatie maken. Wie heeft daar de broek aan? Zwaait de scepter? Dat wordt op dit moment op elke plek afzonderlijk uitgewerkt. Lokale gebruiken en krachten spelen een rol. De visie van de bestuurders is van belang. Acceptatie op de werkvloer is essentieel. Begrijpt $u$ het nog?

\section{Nu 2, interactie}

Voor ik de vertaling naar de praktijk met u bespreek wil ik u graag mijn visie geven over de relatie tussen de internisten acute geneeskunde en de SEHartsen; in veel ziekenhuizen samen op de werkvloer. Zij werken idealiter nauw samen in de verlening van zorg aan patiënten met acute medische hulpvragen. Er is overlap van expertise gebieden. De specialismen zijn complementair, niet uitwisselbaar. Internisten zijn met name bekwaam op het gebied van complexe zorg, bijvoorbeeld bij de oudere patiënten. De SEH arts heeft meerwaarde in de acute opvang van de kritiek zieke patiënt. 
In algemene zin gesproken is duidelijk dat dokters zich niet moeten begeven buiten hun competentiegebied, het gebied waarin ze getraind zijn. Invulling van de zorgvraag buiten het eigen competentiegebied kan niet zonder risico's en is niet in het belang van de patiënten. Voor de spoedzorg betekent dit dat de internist acute geneeskunde niet vervangen kan worden door een andere specialist, ook niet in het eerste uur. Het eerste uur, door sommigen als golden hour omschreven, daarin moet het gebeuren. Geen valse start. Ziekenhuisbestuurders moeten zich dit goed realiseren bij de inrichting van hun organisatie. De internisten moeten zich goed realiseren welke verantwoordelijkheid ze hebben en daar invulling aan geven. Ook de internisten moeten hierin emanciperen, transformeren naar de nieuwe wereld. De veranderde wereld.

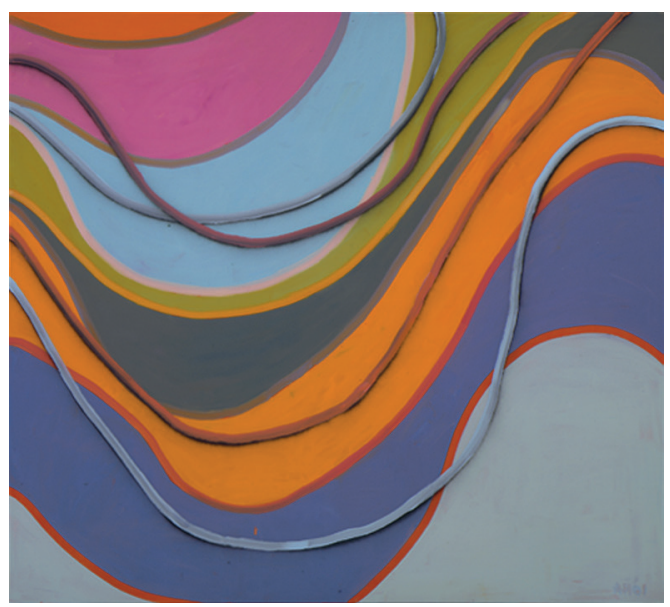

Meerdere wegen leiden naar Rome. Niet elke organisatie zal dezelfde oplossing kiezen. Maar, gegeven de opkomst van de SEH-artsen, gegeven het steeds meer terugtrekken van de chirurg, en gegeven de ontwikkeling van de acute interne geneeskunde zal het leidende team op de SEH een samengesteld profiel dienen te hebben. De SEH-arts $7 \times 24$ uur present en logistieke baas. De acute internist voor de patiënten van de interne geneeskunde en beschouwende vakken. De SEH-arts is vooral betrokken bij de traumazorg, en alle ongedifferentieerd verwezen patiënten. De SEH-arts is tevens vooruitgeschoven post en verantwoordelijk voor de zorg van alle specialismen die hun aanwezigheid en/of hun competenties voor de SEH niet kunnen waarmaken. De chirurg is beschikbaar bij grote trauma's en andere gecompliceerde acute chirurgische problematiek, 
zoals buiken en bloedingen. SEH-arts en internist acute geneeskunde vormen het hart van het team, met de chirurg in nabijheid. Deze drieeenheid zal zich flexibel, op voet van gelijkwaardigheid en zonder financiële prikkels moeten organiseren op de werkvloer.

Samenwerken. Flexibel samen.

Communicatie. Belangrijk.

Welke informatie komt er vanuit de verwijzer. En als de arts op de SEH klaar is, welke informatie geeft die dan terug naar de verwijzer. En: welke informatie gaat naar de arts die voor de patiënt zorgt wanneer deze vanuit de SEH in het ziekenhuis opgenomen wordt. Het overdragen van de zorg voor patiënten kent risico's en is een bron van vergissingen en fouten. Ongeveer $80 \%$ van de in het ziekenhuis opgenomen patiënten interne geneeskunde komt binnen via de SEH. Mede daarom is het verstandig, essentieel wat mij betreft, aan te bevelen dat de interne geneeskunde zelf die patiënten ziet en opneemt. In het eigen systeem, al dan niet met hulp van de SEH-arts. De internist is verantwoordelijk vanaf de start. Vermijd het risico van een valse start.

Het doel is de juiste zorg op het juiste moment voor de patiënt.

Tijdverlies, gezondheidsverlies.

Zoals ik in het begin van dit verhaal zei', het gaat om veilige, doelmatige zorg met de thema's: kwetsbaarheid, teamwork en logistiek.

\section{$\mathrm{Nu}$ 3, op zoek naar gezondheidswinst.}

Alle ziekenhuizen hebben een veiligheidsmanagementsysteem (VMS) dat door de Inspectie voor de Volksgezondheid (IGZ) wordt gecontroleerd. Er zijn 10 thema's waarbij veel gezondheidswinst is te behalen. Een van die thema's betreft de kwetsbare ouderen. Deze ouderen worden vooral gescreend op delirium, vallen, ondervoeding en fysieke beperkingen. Er zijn richtlijnen voor wat er binnen 24 uur na opname gedaan moet worden op deze gebieden. Het proces bij opname, de periode van naar, op, en weer weg van de SEH blijft buiten beschouwing. Opname van kwetsbare oudere patiënten in het ziekenhuis via de spoedeisende hulp. Het terrein van de spoedeisende hulp. Mijn onderzoek bevindt zich juist op dat speelterrein. Ik zal me in mijn onderzoek vooral richten op die oudere patiënt in het proces op en rond de spoedeisende hulp. 
Oudere patiënten maken 10 tot $20 \%$ deel uit van het totaal aantal bezoeken aan de SEH. Dit aandeel zal in de komende jaren toenemen. Specifieke problemen die een rol spelen bij oudere patiënten zijn: complexiteit, zoals multiple comorbiditeit, atypische klachten, polyfarmacie, ze worden vaker hergepresenteerd op SEH, en krijgen vaker iatrogene complicaties dan jongere patiënten.

Ouderen kunnen hun klachten vaak niet goed duiden.

LOL in NAD, ik kom hierop terug.

Logistieke processen op de SEH zijn algemeen en niet specifiek ingericht voor oudere patiënten. Triage instrumenten zijn niet gevalideerd voor oudere patiënten. Er zijn aanwijzingen dat oudere patiënten ondergetrieerd worden, waardoor diagnosestelling en therapeutische interventies worden vertraagd, en waardoor de uitkomst voor de patiënt negatief wordt beïnvloed.

Niet alle ouderen zijn kwetsbaar. Er zijn verschillende indices ontwikkeld om kwetsbaarheid te onderkennen, maar die zijn nog onvoldoende betrouwbaar en toepasbaar gebleken.

Het terrein van de acute interne geneeskunde grenst aan en overlapt in het ziekenhuis met dat van de SEH-artsen en chirurgen. Ook zijn er relaties met andere specialismen die patiënten binnen krijgen via de $\mathrm{SEH}$, zoals neurologie, cardiologie en pulmonologie. Met de eerste lijn is er een verwijs- en overdrachtsrelatie die van wezenlijk belang is voor het goed functioneren van de keten naar en van het ziekenhuis.

Het onderzoeksprogramma van de acute geneeskunde met focus op ouderen past goed in de onderzoeksschool CAPHRI, en met name in het programma "Innovations in health care for the elderly" onder leiding van de hoogleraren Kempen en Hamers.

\section{Wetenschap, mijn onderzoek}

In mijn onderzoek richt ik me op de eerder besproken thema's: kwetsbaarheid, team en logistiek.

Voor het onderzoek is een database aangelegd. Hierin geregistreerd zijn alle bezoeken aan de SEH van het MMC van patiënten interne geneeskunde van 65 jaar en ouder, alsmede een controlegroep van 
patiënten onder de 65 jaar. In totaal een kleine 2500 patiënten - bezoeken. Deze database is met de hand aangelegd door Steffie Brouns en bevat patiëntkarakteristieken, voorgeschiedenis, presenterende klachten, vitale parameters, diagnostiek, diagnoses, behandeling, opnamegegevens en uitkomsten, inclusief sterfte na één jaar. Ook het volledige logistieke proces, met nadruk op de doorlooptijden op de SEH, is opgenomen.

'Met de hand' zult $U$ denken, een flink karwei, kan dat niet sneller en beter? Ja, dat kan, maar is niet makkelijk. Meerdere ziekenhuizen richten zich hierop met hulp van externe, commerciële bedrijven. Wij zijn in staat geweest met onze eigen mensen van de ICT en het EPD een tweede database aan te leggen met daarin opgenomen de SEH-bezoeken voor alle specialismen gedurende een periode van twee jaar. In totaal ongeveer 60.000 patiënten - bezoeken. Deze database is minder compleet dan de handmatige, en bevat minder gegevens over voorgeschiedenis en opname. Een ander probleem is dat diverse items, zoals de presenterende klacht en ook de diagnoses, alleen als woord zijn toegevoegd. De gemakkelijke codering ontbreekt. Dus ook in die database moet nogal wat handwerk gedaan worden.

Op het thema kwetsbaarheid hebben we gekeken naar biomarkers. Er is een wens, zo u wilt een tendens, om naar merkstoffen te kijken die het beloop van de ziekte van de patiënt voorspellen. Bij patiënten in shock bijvoorbeeld is het lactaatgehalte een indicator van de ernst van de shock. Er zijn aanwijzingen voor een prognostische waarde van allerlei bepalingen die in dit veld van belang zijn. Pro-ADM, D-dimeer etc. In onze database hebben we naar een marker gekeken die vaak wordt bepaald voor algemeen screenende overwegingen: het Natriumgehalte. Natriumzout is een essentieel bestanddeel van ons milieu intérieur. We bepalen het Natrium vanuit de interne geneeskunde met het doel te kijken hoe het gesteld is met het water-en-zoutgehalte van het lichaam. Afwijkingen zijn vaak medeverklarend voor de klachten en verschijnselen van de actuele situatie van de patiënt op de SEH. Met het corrigeren van het Natrium kunnen we die actuele situatie verbeteren samen met andere maatregelen om te genezen of klachten te doen verminderen. Dat is korte termijnwinst. 


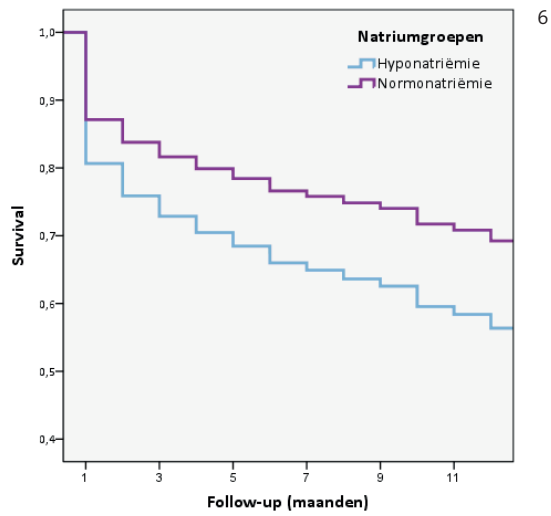

Overleving van patiënten $>65$ jaar; hyponatremie versus normonatremia correctie voor leeftijd, Charlson Comorbidity Index en medicijn gebruik

Als we in onze database kijken naar de voorspellende waarde van Natrium bij de oudere interne patiënt, dan blijken patiënten met een verlaagd Natrium een verhoogde kans op sterfte te hebben in de opvolgende maanden tot één jaar na dato. ${ }^{6}$

Natrium is dus een biomarker van kwetsbaarheid, frailty. In onze database zullen we andere factoren van kwetsbaarheid nader bekijken.

Over kwetsbaarheid gesproken.

LOL in NAD en Gomers.

Kent $u$ het boek "House of God" van Samuel Shem? Dokters van mijn leeftijd vast wel, jongere misschien ook.

Een LOL in NAD is in dat boek een "little old lady in no apparent distress". En Gomers zijn de zogenaamde "Go out of my emergency room patients". Deze figuren, in een andere tijd beschreven, maar nog steeds herkenbaar in onze huidige praktijk, lijken niet kwetsbaar. Maar is dat ook zo? Hoe komen we daar achter?

Kwetsbaarheid herkennen is belangrijk. Niet herkennen leidt tot verslechtering van de toestand, tot het eerder ontstaan van complicaties, en mogelijk zelfs tot sterfte, onnodige sterfte. Indices voor kwetsbaarheid zijn ontwikkeld. Eerder en elders. Goede indices met een betrouwbare, voorspellende waarde zijn er helaas niet. 
De klinische blik van de dokter, verpleegkundige hoe zit het daarmee zult u misschien denken? Volstaat die niet?

Nee, die volstaat niet, maar is wel belangrijk. De aanblik van een patiënt, hoe ligt hij of zij erbij. Is de patiënt alert? Ademt ie rustig? Een hand op de neuspunt en op het voorhoofd is een methode van de oudere dokter, mijn opleiders vroeger, om te kijken hoe het is. Koude neuspunt, klam voorhoofd, dan de pols voelen. Snel en zacht, weinig kracht, de patiënt is er niet goed aan toe.

Kritiek zieke patiënten worden op de SEH als urgent getriëerd. Zij dienen direct geholpen te worden. Niet in de wachtkamer dus. De jonge dokter, dat wil zeggen de dokters van tegenwoordig, benaderen de kritieke patiënt op de SEH gestructureerd, anders dan voorheen. ABCDE-methode. Ademweg vrij? Ventilatieproblemen? Hoe is de circulatie? Neurologische beoordeling en onderzoek naar de blootstelling aan omgevingsfactoren. Gestructureerd en herhaald.

"Treat first what kills first".

De niet-kritiek zieke patiënt op de SEH, de grootste groep patiënten, wordt na triage in de wachtkamer geplaatst. Afhankelijk van de triage is er dan een volgorde van oproep voor de consultatie en wat daarbij verder komt kijken. Van die grote groep mensen zonder herkende kritieke ziekte vormt de oudere mens de grootste groep.

Deze oudere patiënten hebben vaak een complex probleem, multiple comorbiditeit, atypische klachten, polyfarmacie. Zij zijn of worden vaker heropgenomen en krijgen vaker iatrogene complicaties dan jongere patiënten.

Zeker als de cognitie is gestoord worden de klachten bij presentatie niet altijd op de juiste waarde geschat. Oudere mensen worden dan ondergetrieerd, verblijven dan langer in de wachtkamer dan goed voor hen is. Valse start.

Wanneer de herkenning van kwetsbaarheid faalt is er sprake van een valse start. Een valse start leidt tot diskwalificatie, dat weet u. Valse start geeft schade, dat begrijpt $u$. Delay van diagnostiek, diagnosestelling en behandeling.

Wanneer kwetsbaarheid niet voldoende herkend wordt, moeten we in mijn perceptie alle mensen als kwetsbaar beschouwen. Kwetsbaar tenzij we zeker weten dat ze het niet zijn. Dit systeem met tenzij komt dan in 
de plaats van "we beschouwen de mens kwetsbaar als we kwetsbaarheid herkennen, wie we niet als kwetsbaar herkennen heeft pech".

Het concept 'kwetsbaar tenzij' gaan we in onze database onderzoeken. De patiënten met goede uitkomst - geen overlijden, geen complicaties, geen heropnames, geen herpresentaties op SEH - willen we in onze grote database identificeren en vergelijken met de karakteristieken van de overige. Dit onderzoek is een samenwerking met het team van professor Uzay Kaymak van de Technische Universiteit Eindhoven. Uitkomst zonder problemen staat niet volledig gelijk aan de classificatie niet-kwetsbaar. Immers ook kwetsbare patiënten kunnen een ongestoord beloop hebben. Maar de uitkomsten van de analyse kunnen we, gecombineerd met andere eenvoudig te verkrijgen gegevens, prospectief testen op onze spoedeisende hulpen in MMC en Maastricht. Dit onderzoek van MUMC, MMC en TU/e kan een belangrijke bijdrage leveren aan de organisatie van de zorg in de toekomst.

Van het thema kwetsbaarheid nu naar team en organisatie.

In mijn ziekenhuis, het MMC, vormen de SEH-arts en de internist acute geneeskunde een team op de SEH. De SEH-artsen bevinden zich in een proces van uitbreiding. De SEH zit organisatorisch in een overgangsfase waarbij de SEH-arts de leider van de spoedzorg moet worden. Met name chirurgen en orthopeden profiteren van deze ontwikkeling. Deze specialisten kunnen de toestroom in de huidige tijd niet meer op eigen kracht opvangen. Voor de interne geneeskunde, waar het volume van zorg in absolute zin lager is ligt dat anders. De internisten kunnen wel $7 \times 24$ uur dekking bieden.

In Maastricht is er geen SEH-arts. De patiënten worden gezien door verpleegkundig specialisten en chirurgen, al dan niet in opleiding, voor trauma's of chirurgisch gerelateerde problematiek. Voor de beschouwende patiënten is de internist of internist in opleiding aanwezig, 7×24 uur. Ook de andere beschouwers zoals neurologen, longartsen en cardiologen hebben zo'n systeem.

De vraag doet zich voor hoe het systeem zonder SEH-arts, Maastricht, zich kwalitatief verhoudt tot het systeem met SEH-arts, zoals in MMC. Een organisatie zonder SEH-arts is niet uniek. Ook het UMCU heeft dat systeem met een internist acute geneeskunde en een chirurg als centrale dokters op de SEH. 
Samen met Lisette Mignot, SEH-arts MMC, gaan we proberen te onderzoeken hoe het team met de SEH-arts functioneert in vergelijking met een team zonder SEH-arts.

Organisatie van zorg. Samenstelling van de teams. Meerdere wegen naar Rome. We moeten de meest veilige weg identificeren. De meest veilige weg voor doelmatige zorg.

De toestroom naar de SEH wisselt gedurende de week. Op vrijdagen komen de meeste mensen. Op zaterdag en zondag de minste. Overdag is de grootste toestroom met een piekmoment in de middag. Psychische factoren en bedrijfstechnische factoren, met name van de eerste lijn, liggen hier mede aan ten grondslag. Het team van de SEH zal zijn organisatie hierop moeten aanpassen. Organiseer de spoed. Stel het team samen rekening houdend met de bekende piek- en dalmomenten. Maak het systeem flexibel op samenstelling en inhoud. Competenties op afroep.

Een inschatting van de drukte op de SEH kan gegeven worden door middel van de EDWIN score. In deze score wordt gekeken naar het aantal aanwezige patiënten, de triagecategorie per patiënt, het aantal aanwezige artsen en het aantal beschikbare bedden in relatie met het aantal bezette bedden op de SEH. De EDWIN score wordt in onze grote database onderzocht. Dat onderzoek kan leiden tot adviezen om de inzet van personeel en ruimte anders in te richten.

Langer verblijf op de SEH is in de literatuur geassocieerd met complicaties, slechtere zorg. Ontevreden patiënten.

Analyse van de logistiek in onze database toont ons dat de oudere patiënten een half uur langer op de SEH verblijven dan jongere. De factoren van invloed op die langere verblijftijd zijn het aantal verrichte diagnostische testen, het aantal consulten van andere specialisten en de senioriteit van de verantwoordelijke, eerste dokter. Met name de inzet van semi-artsen en arts-assistenten niet in opleiding is geassocieerd met een langere verblijfsduur op de SEH van oudere patiënten. Logisch zult u denken. Maar in onze analyse is bij de jongere controlegroep alleen het aantal consulten significant geassocieerd met een langere verblijfsduur op de SEH. ${ }^{7}$

Comorbiditeit in zowel de oudere als de jongere groep was niet van invloed op de verblijfsduur. Hogere urgentie van zorg, SEH presentatie gedurende de nacht of in het weekend was geassocieerd met een kortere verblijfsduur van oudere patiënten.

Naast medische factoren zijn er dus ook organisatorische factoren van invloed op de kwaliteit van zorg. 


\begin{tabular}{lrr}
\hline & $\begin{array}{r}\text { Patiënten } \geq 65 \text { jaar } \\
\text { OR }(95 \% \mathrm{CI})\end{array}$ & $\begin{array}{r}\text { Patiënten < 65 jaar } \\
\text { OR (95\% CI) }\end{array}$ \\
\hline Urgent triage niveau & $0.4(0.2-0.6)$ & - \\
Weekend presentatie & $0.7(0.5-0.9)$ & - \\
Nacht presentatie & $0.4(0.2-0.7)$ & $2.6(1.4-4.6)$ \\
Zelf-verwijzer & $3.2(2.3-4.3)$ & - \\
$>1$ consult op SEH & & - \\
Arts op SEH & $4.2(2.0-8.8)$ & \\
$\quad$ Semi-arts & $2.3(1.4-3.9)$ & \\
$\quad$ ANIOS & $1.24(1.16-1.33)$ & \\
Aantal diagnostische tests op SEH & & \\
\hline
\end{tabular}

Medische en organisatorische factoren in relatie tot verblijfsduur op SEH

Op dit moment wordt in samenwerking met de TU/e de zorg op de SEH als een logistiek proces in kaart gebracht d.m.v. een simulatiemodel. In dit model kunnen op theoretische basis oplossingen worden gezocht voor logistieke problemen. Organisatieaanpassingen in de zorg. Deze oplossingen kunnen vervolgens in de praktijk worden toegepast. Nulmeting en meting tijdens simulatie van de doorlooptijden, patiënttevredenheid, alsmede kwaliteitsindicatoren en efficiencyparameters worden vervolgens gemeten en gerapporteerd.

Ik heb met $u$ het toen besproken en uitgebreid stilgestaan bij het nu. En daarna komt straks.

\section{Straks}

Ik heb u natuurlijk al wel veel verteld over straks. Je kan immers niet in het nu leven als je straks niet in beeld houdt.

Straks hoop ik dat mijn onderzoek bijdraagt aan een veilige en doelmatige zorg. Met name voor ouderen met een acuut medische zorgvraag.

Het onderzoek zal in MUMC en MMC plaatsvinden. In samenwerking met de Technische Universiteit Eindhoven.

In samenwerkingsverband met het Nederlands onderzoeksconsortium acute interne geneeskunde.

Ook samenwerking in Europa ligt in de lijn der verwachting. Hierover zijn in mei jongstleden de eerste gedachten gewisseld.

Ik stel me voor dat er straks zorgstraten zijn ontwikkeld van de eerste lijn naar de tweede lijn, ook voor de patiënt met aspecifieke klachten. Deze zorgstraten zijn eigendom van eerste en tweede lijn, begeven zich dus over de grenzen heen. 
Met de acute internist als teamspeler. In een centrale rol voor de beschouwende problemen, in een dienende rol bij overige problemen.

Dat ziet er dan goed uit. "All is Well".

Geachte toehoorders. Mijn betoog komt ten einde.

Ik heb $\mathrm{u}$ verteld over toen, nu en straks. Ik heb $\mathrm{u}$ laten zien dat kunst een rol kan spelen in het ziekenhuis. Ziekenhuis, huis van genezing. Genezing die ook op alternatieve plaatsen wordt gezocht en soms gevonden. Alternatieve genezing in een museum bijvoorbeeld. Ik verwijs hiervoor naar de tentoonstelling in het Rijksmuseum in Amsterdam. Daar is tot 7 september de tentoonstelling "Art Is Therapy" te zien. Enkele jaren geleden heb ik in een campagne voor het Van Abbemuseum al in een advertentie in de lokale krant hierop gewezen. Mijn bron, mijn moderne "well" van Aesculapius, ik wil het u niet onthouden, is het Van Abbemuseum. "Het Van Abbe maakt beter". 


\section{Dank}

Ik dank u, mijnheer de Rector Magnificus, het College van Bestuur van de Universiteit Maastricht voor het in mij gestelde vertrouwen. Door het instellen van de eerste leerstoel in de acute interne geneeskunde spreekt $u$ vertrouwen uit in de acute interne geneeskunde als wetenschap en als onderdeel van het grote vakgebied interne geneeskunde.

Leden van de raad van bestuur van het Máxima Medisch Centrum, hooggeleerde Zwaveling in het bijzonder. Het is voor mij een eer en voorrecht te mogen werken in uw en mijn ziekenhuis. De visie die het ziekenhuis heeft om in te zetten op een STZ status, met bijbehorend opleidings- wetenschapsprofiel, is sedert vele jaren een drijfveer. Als opleider interne geneeskunde heb ik in meer dan 20 jaar hieraan mijn bijdrage mogen leveren. Ook bestuurlijk in een belangrijke periode, maar de laatste jaren vooral ook als decaan van ons ziekenhuis. Ik ben trots om deze leerstoel namens het MMC in te mogen vullen. Ik ben dankbaar voor de gelegenheid die u heeft gecreëerd.

Hooggeleerde Stehouwer, beste Coen. Jij bent een decennium hoofdopleider en hoofd van de interne geneeskunde. Gedurende deze jaren hebben we een stevige werkrelatie opgebouwd. Enkele malen per jaar bespraken we lokale, regionale en landelijke problemen en kansen tijdens jouw bezoeken aan het MMC of op een ander moment. Door jouw inzet en visie is de kwaliteit en kwantiteit van opleiden in de interne geneeskunde in onze regio op een hoog niveau gekomen. Met de hooggeleerde Koopmans aan jouw zijde. Dank voor de steun en het geven van de mogelijkheid om deze leerstoel in te vullen en daarmee onderdeel van jouw afdeling te worden. Ik verheug me op de verdere samenwerking.

Hooggeleerden Kempen en Hamers, beste Ruud en Jan. De zorg voor de mens bestaat uit een continue samenwerking tussen eerste en tweede lijn. Het onderzoek naar de kwetsbare ouderen kan door samenwerking tussen onze afdelingen een boost krijgen. Gerichte interventies in transmurale zorgsysteem. Ik verheug me op de samenwerking.

Collegae acute internisten. In de afgelopen jaren is er veel werk verricht. De visie en inzet van velen heeft ons inmiddels ver gebracht. Mijn dank aan allen om met jullie dit mee te maken. Namen zijn er veel. Ik wil op deze plaats Tom Geers, Ineke Schouten en Jan ter Maten specifiek noemen. Prabath Nanayakkara is een rijzende ster samen met Patricia 
Stassen en Stephanie Klein Nagelvoort. Karin Kaasjager de volgende hoogleraar in ons vakgebied. Met jullie en al die anderen gaan we de ontwikkeltocht vervolgen. Ik verheug me zeer.

Zeergeleerde Stassen, beste Patricia. Jij hebt als leider van de internisten acute geneeskunde van Maastricht al een solide organisatie neergezet. In het team de collegae Rennenberg, Henry, Koopmans, Borggreve, Vanmolkot en Posthouwer. Met jouw creatieve geest sta je al voorop in het veld van de acute geneeskunde. Tijdens de internistendagen ben jij de laatste jaren de hoogst scorende internist qua inzendingen en prijzen. Mijn respect is groot, zeker gezien de beperkte mogelijkheden aan jou gegeven. Samen gaan we een sterk team vormen voor een mooie toekomst.

Hooggewaardeerde vrienden en vriendinnen van de maatschap interne geneeskunde en Maag Darm en Leverziekten. We hebben een groeiende club met betrekking tot aantal en met betrekking tot inhoud. Kwaliteit komt steeds meer voorop. Ik ben jullie heel dankbaar voor de ruimte die ik kreeg om te groeien op organisatorisch en wetenschappelijk terrein.

Beste arts-assistenten en studenten geneeskunde die ik in mijn carrière als opleider interne geneeskunde heb mogen begeleiden. Ik wil jullie danken voor de inspiratie die ik heb mogen ervaren vanuit de opleidingssituatie in al die jaren. Mede geïnspireerd door jullie frisse geesten kan ik, als internist in een gevorderde fase van mijn carrière, beginnen aan een nieuwe, uitdagende periode.

In herinnering aan mijn ouders die dit niet, dan wel niet meer bewust mee kunnen maken. Mijn vader was mijn voorbeeld. Ik heb hem bewust nooit willen nadoen of opvolgen. Onbewust heb ik hem ongeveer volledig gekopieerd. We lijken veel op elkaar. Ik weet dat je trots zou zijn, dat je trots bent.

Mijn moeder kan deze dag door Alzheimer niet bewust meemaken. Maar ze is trots en elke keer blij als ik bij haar langs kom. Dankzij jouw steun, nog elke dag, ben ik hier.

Lieve Floor, Bas en Hester. Het liefste en mooiste gezin. Ik houd van jullie. Wat ik heb en wat ik bereik is dankzij jullie, en is voor jullie. Floor heeft zich altijd weggecijferd voor mij en onze kinderen. Enkele jaren geleden had jij ook zo'n positie kunnen aanvaarden. Je hebt toen niet een stap willen maken. Nu wel. Nu ben je gepromoveerd tot bestuurder. Alweer samen gepromoveerd zoals in 1993. Ik steun jou, altijd, zoals jij mij steunt. 
Dames en heren toehoorders.

ik heb gezegd, "All is Well" 


\section{Referenties}

1. "All is Well". Aya Ben Ron. Máxima Medisch Centrum Eindhoven. 2013.

2. René Descartes. Principia philosophiae. 1644.

3. "Dream" http://www.mmc.nl/alliswell

4. "Think" http://www.mmc.nl/alliswell

5. Anton Henning. Interieur \# 86. Olie op canvas, 2001, $193 \times 213 \mathrm{~cm}$.

6. SHA Brouns, MKJ Dortmans, FS Jonkers, SLE Lambooij, A Kuijper, HR Haak Hyponatremia in Elderly Emergency Department Patients: A Marker of Frailty. Neth J Med. 2014; 72 (6):311-317.

7. SHA Brouns, SLE Lambooij, J Dieleman, ITPVanderfeesten, PM Stassen, HR Haak. Organizational Factors induce Prolonged Emergency Department Length of Stay in Elderly Patients. Abstract SAMsterDAM. 2014. 
